\title{
Theoretical basis for the formation of damaging factors during the coal aerosol explosion
}

\author{
Olena Zavialova ${ }^{1 * \otimes(\odot)}$, Viktor Kostenko ${ }^{1 \otimes(\odot)}$, Natalia Liashok ${ }^{1 \otimes(\bullet)}$

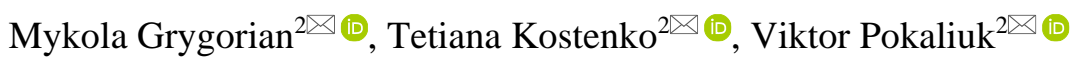 \\ ${ }^{1}$ Donetsk National Technical University, Donetsk, 85300, Ukraine \\ ${ }^{2}$ Cherkasy Institute of Fire Safety named after Chornobyl Heroes of National University of Civil Defense of Ukraine, Cherkasy, 18034, Ukraine \\ *Corresponding author: e-mail elenazavialova63@gmail.com, tel.+380953104483
}

\begin{abstract}
Purpose. Assessing the process of damaging factors formation during the coal aerosol explosion in mine workings on the basis of theoretical research of the explosion of coal dust deposits in order to substantiate promising methods of protecting miners from their impact.

Methods. An integrated approach is used, which includes a critical analysis of literature data on the occurrence and development of coal aerosol explosions in mine workings; theoretical research into the state of the gaseous medium at the characteristic points of the development diagram of the coal dust deposits explosion as a result of mining operations based on the laws of classical physics and chemistry.

Findings. The main aspects of the explosion mechanism of dust in a powdery state, accumulated on the surfaces along the mine working perimeter, and the formation of such negative factors as the effect of gaseous medium accelerated movement, have been revealed; high temperature formed during coal and methane detonative combustion; increased gas pressure. The revealed aspects of the dust explosion mechanism make it possible to determine the main directions for protection of miners caught in the explosion. The diagram of the development of settled coal dust explosion along the mine working with normal ventilation conditions, taking into account the influence of seismic waves, has been improved.
\end{abstract}

Originality. Analytical dependences, reflecting the value of gas energy at characteristic points of the diagram, have been determined, and the dynamics of the formation of negative factors caused by the explosion have been revealed.

Practical implications. Possible ways of protecting miners from the impact of negative factors caused by the coal aerosol explosion and reducing the severe consequences of such accidents are proposed.

Keywords: explosion, coal dust, flame front, shock wave, seismic waves, damaging factors, miners 'protection

\section{Introduction}

Over the past four decades, about three dozen explosions of air-methane mixtures or hybrid mixtures of coal dust with methane and air have occurred in Ukrainian coal mines (Table 1). As a result, 1349 miners were injured, of which 732, that is, $65 \%$ of those caught in the accident, were fatally injured [1], [2]. The occurrence of such accidents was provoked by such sources as drilling-and-blasting operations, heating of parts by friction, malfunction of electrical equipment, spontaneous combustion of coal, etc.

Explosions of methane and hybrid mixtures occur in coal mines around the world, even at the enterprises with high technological culture, such as the United States and Poland, they occur every ten years [3]. The reason for the high level of fatal injuries and severe consequences, such as burns, poisoning, mechanical and barotrauma, is the formation during the explosion of a set of adverse negative factors, namely high pressure, velocity of movement and temperature of the gaseous medium with the highly toxic components formed in it and the simultaneous deficiency of oxygen [4].

The most large-scale, both in terms of injuries and material damage, are explosions that spread over a network of mine workings over long distances. Moreover, the content of methane and dust in the air is much lower than the minimum limits of their flammability. Thus, the combustible material is coal, which accumulates in the form of a powder on surfaces along the mine working perimeter [3].

The catastrophic consequences of explosions are conditioned by the fact that the damage area spreads over considerable distances from the source of occurrence, capturing the workplaces of miners [4]. 
Table 1. Explosions of methane-air (MAM) and hybrid dust-air (DAM) mixtures in mines of Ukraine [1], [2]

\begin{tabular}{|c|c|c|c|c|c|}
\hline \multirow[b]{2}{*}{ Mine } & \multirow[b]{2}{*}{ Explosion date } & \multirow[b]{2}{*}{ Explosive } & \multicolumn{2}{|c|}{ Injured, pers. } & \multirow{2}{*}{$\begin{array}{l}\text { Ignition } \\
\text { source* }^{*}\end{array}$} \\
\hline & & & Total & $\begin{array}{l}\text { Fatally } \\
\text { injured }\end{array}$ & \\
\hline V.M. Bazhanov Mine & $09 / 25 / 1978$ & MAM + DAM & 24 & 24 & no data \\
\hline O.O. Skochinsky Mine & $07 / 27 / 1979$ & MAM + DAM & 9 & 7 & DBO \\
\hline Molodohvardiiska Mine & $08 / 10 / 1979$ & MAM + DAM & 71 & 55 & $\mathrm{FS}$ \\
\hline Hirska Mine & $04 / 26 / 1980$ & MAM + DAM & 99 & 66 & DBO \\
\hline G. Dymytrov Mine & $02 / 03 / 1985$ & MAM + DAM & 24 & 12 & DBO \\
\hline LLC Novohrodivska Mine & $05 / 28 / 1985$ & DAM & 5 & 5 & DBO \\
\hline Yasynivska-Hlyboka Mine & $12 / 24 / 1986$ & MAM & 40 & 30 & EP \\
\hline Chaikino Mine & $05 / 16 / 1987$ & MAM & 50 & 36 & FS \\
\hline Sukhodilska-Skhidna Mine & $06 / 09 / 1992$ & MAM + DAM & 116 & 63 & EP \\
\hline O.O. Skochynskoho Mine & $08 / 21 / 1992$ & MAM & 43 & 17 & DBO \\
\hline O.F. Zasiadka Mine & $05 / 24 / 1999$ & MAM & 99 & 50 & $\mathrm{~F}$ \\
\hline Krasnolymanska Mine & $01 / 21 / 2001$ & MAM & 24 & 9 & no data \\
\hline S.M. Kirova Mine & $05 / 05 / 2001$ & MAM & 47 & 10 & EP \\
\hline O.F. Zasiadka Mine & $08 / 19 / 2001$ & MAM + DAM & 88 & 55 & $\mathrm{~F}$ \\
\hline Yuvileina Mine & $07 / 21 / 2002$ & MAM & 36 & 6 & EP \\
\hline O.F. Zasiadka Mine & $07 / 31 / 2002$ & MAM + DAM & 31 & 19 & DBO \\
\hline Krasnolymanska Mine & $07 / 19 / 2004$ & MAM + DAM & 49 & 37 & EP \\
\hline Sukhodilska-Skhidna Mine & $08 / 13 / 2006$ & MAM & 13 & 8 & no data \\
\hline O.F. Zasiadka Mine & $11 / 18 / 2007$ & MAM + DAM & 150 & 101 & $\mathrm{DBO}$ \\
\hline O.F. Zasiadka Mine & $12 / 01 / 2007$ & MAM + DAM & 52 & 0 & $\mathrm{~F}$ \\
\hline O.F. Zasiadka Mine & $12 / 07 / 2007$ & MAM + DAM & 71 & 5 & $\mathrm{~F}$ \\
\hline Karla Marksa Mine & $06 / 0 / .2008$ & MAM & 42 & 13 & DBO \\
\hline S.M. Kirov Mine & $23 / 08 / 2009$ & MAM & 20 & 8 & EP \\
\hline Sukhodilska-Skhidna Mine & $07 / 29 / 2011$ & MAM + DAM & 28 & 28 & $\mathrm{DBO}, \mathrm{EP}$ \\
\hline O.F. Zasiadka Mine & $03 / 04 / 2015$ & MAM & 50 & 34 & no data \\
\hline Maloivanivska Mine & $05 / 02 / 2016$ & MAM & 12 & 9 & EP \\
\hline Stepova Mine & $03 / 02 / 2017$ & MAM & 36 & 8 & EP \\
\hline Skhidkarbon Mine & $04 / 25 / 2019$ & MAM & 20 & 17 & no data \\
\hline
\end{tabular}

${ }^{*} E P$ - electrical power; DBO-drilling-and-blasting operations; FS-frictional sparking; $F$ - fire; no data-no data available

The existing methods and measures for localizing explosions, as well as protecting people, do not always fulfill their functions due to their imperfection or inability to counteract some of the many damaging factors.

Explosions of methane or hybrid mixtures have been investigated for over two centuries [4]. However, due to the impossibility of direct investigation of this process in situ, as well as the complexity of physical modeling and other reasons, there are still no objective ideas about the mechanism of damaging consequences formation caused by explosions. Research on reducing the impact of negative explosion factors and creating means of protecting miners from them remain relevant.

\subsection{Actual scientific research and publications analysis}

The pecularities of the explosion of methane-air mixtures and hybrid mixtures of methane, combustible dust and air are intensively studied all over the world. The flame characteristics and propagation of a coal dust explosion caused by a methane explosion have been studied in a horizontal pipeline system. The coal dust involved in the methane explosion has much longer flame duration and brighter flame than in the case of methane explosion. Provided that no other fuel is involved in the explosion, the retardation of the flame wave behind the pressure wave rapidly increases with increasing length-to-diameter ratio [5]. In a sphere with a volume of 20 liters, the influence of fuel concentration and its particle size on multiple explosion parameters has been studied for mixtures of coal and methane particles. The results have shown that the concentration of the fuel and the particle size have a large influence on the explosive hazard of methane/coal dust mixtures [6].
In a vertical shock tube, the processes of combustion, explosion and detonation in hybrid systems containing gas mixtures of $\mathrm{CH}_{4} /$ air, $\mathrm{CH}_{4} / \mathrm{O}_{2}$ and $\mathrm{O}_{2} /$ coal with a size of up to $200 \mu \mathrm{m}$ and a volume-average density of up to $700 \mathrm{~g} / \mathrm{m}^{3}$ are studied. It has been revealed that in hybrid systems, coal dust has a smaller influence on the parameters of combustion and detonation waves than methane, and that methane in these waves is more active than coal dust [7]. Experiments with lowconcentration coal dust are conducted on an installation for explosion of a dust-gas-coal mixture. The results indicate that with the addition of low-concentration coal dust, the pressure of the gas explosion and the velocity of the explosion flame propagation increases. The content of volatile substances in coal dust and the content of gas have a decisive influence on the explosion parameters. When the methane concentration is $9.5 \%$, the flame propagation velocity reaches the highest level after the addition of coal dust [8]. Using MatLab and Lingo software, three models of mine classification, mine exposure and optimal ventilation required for a mine are studied. The relationship between the gas concentration and the minimum limit of the explosion-hazardous concentration of coal dust has been determined. The functional relationship between the gas concentration and the explosion-hazardous concentration of coal dust is determined using a logarithmic approximation [9]. Modeling has shown that the sharp increase in pressure is caused by additional heat released as a result of exothermic reactions of combustion substances and an increase in the amount of products in the gas phase [10]. It should be noted that the formation of factors that negatively affect people is not studied in the above-mentioned works. 
A significant number of works are devoted to the issue of phlegmatization of explosions with the help of water. The evolution of excess pressure and the law of flame propagation in the explosion of humidified coal dust with different moisture content are studied in a straight shock tube. The experimental results show that at a moisture content of less than $15.12 \%$, the settled coal dust in the pipeline explodes under the influence of a gas explosion. When the moisture content of the moistened coal dust is $9.57 \%$, the excess pressure and flame propagation velocity during the coal dust explosion reach the maximum values of $0.766 \mathrm{MPa}$ and 468.553 $\mathrm{m} / \mathrm{s}$, respectively. However, when the moisture content exceeds $20.28 \%$, the coal dust cannot cause an explosion, and the settled coal dust can resist a gas explosion [11].

When estimating the explosion index, the moisture parameter is used, one of the most important characteristics of coal dust. About 32 coal samples with different moisture content are taken from the mines of Iran. The explosion of coal dust is performed in a closed chamber with a volume of two liters. It has been revealed a reliable correlation between laboratory results and a predictive model obtained using linear regression analysis [12]. A flexible approach is proposed to comply with the requirements of the EN-145912:2007 standard for the specific conditions of the Spanish coal mining industry. Prevention of the propagation of methane and/or coal dust explosions due to the use of passive water barriers has been substantiated [13]. The gas dynamics equation is used for modeling the interaction of shock waves with water obstacles. The model is supplemented by the presence of dispersed water in the flow and the possibility of its settling on the mine working walls. An approach has been developed to implement a method for solving the problem of shock waves propagation in a branched network of mine workings, taking into account the interaction of shock waves with water obstacles [14]. An approach to determining the technically achievable levels of the current average dust concentration in the mine air per shift and methods for increasing the efficiency of assessing the dust content in coal mines are proposed. Methods of objective determination of mass and distribution of dust deposits in underground mine workings are provided [15].

The research on the inhibition of the explosion process using carbonates is continued. In the experimental Barbara mine (Poland), a thin layer of coal dust is spread over a layer of treated or untreated stone dust. The effectiveness of treated and untreated stone dust has been compared for reducing the spread of coal dust explosion caused by strong and weak methane explosions [16]. A problem is the risk of sticking the rock dust particles together. The study has shown that single-layer adsorption of sodium oleate is likely to occur in the oleate concentration range from 0.1 to $0.15 \%$ by weight and provides a free-flowing state of dust [17]. Two methods of limestone dust hydrophobization as an anti-explosive agent are proposed: from stearic acid vapor and from a silicone solution. A preliminary assessment of the properties of this waterproof dust is conducted in accordance with the Polish standard (PN-G-11020) and using powder characterization methods [18]. In the above-mentioned works, the possibility of suppressing the explosive force is studied, but the effect of the accompanying factors that negatively affect the miners is not taken into account.

A number of studies indicate the threat of repeated explosions, which has been repeatedly noted in practice. Using the image processing technology and the theory of fractals, the microstructure of coal dust after the explosion has been qualitatively and quantitatively characterized. After the explosion, coal dust has a more uneven pore surface and a more uniform pore structure. In addition, this research paper demonstrates that post-explosion coal dust has practical value in identifying the involvement of coal dust in an explosion accident and in determining the source of the explosion [19]. To study the threat of repeated explosions, the solid remains of a coal dust explosion have been tested in an explosive installation with a volume of 20 liters. The explosion intensity of the residues is still high, despite the fact that they are weaker than that of coal dust. The residues are characterized by slower flame propagation velocity and a lower heat generation rate than coal dust. Preliminary analysis indicates that bound carbon, instead of volatiles and chemical bonds in these residues, is additionally burned during the repeated explosion [20].

A number of research is devoted to the disclosure of the dust explosion mechanism. It is indicated that it occurs in several stages: formation of an explosion-hazardous airmethane mixture; mixture ignition; beginning of the primary gas explosion; raising of coal dust through the front of the shock wave from the gas explosion and the formation of a dust-air mixture; an increase in the velocity of the flame front propagation from the ignition of dust, the raising of even more dust and the formation of an explosion-hazardous zone ahead of the flame front; dust explosion spreading along the chain of mine workings [21]. The release of volatile gases in volumes sufficient for ignition occurs only in a dust aerosol, the settled dust does not pose a significant hazard until it transitions to a floating (aerosol) state. Gaseous components released from coal dust are not limited to methane (and/or its homologues $-\mathrm{C}_{n} \mathrm{H}_{2 \mathrm{n}+2}$ ). A significant part of volatiles have minimum concentration limits of ignition, combustion temperature, maximum explosion pressure, and other properties different from $\mathrm{C}_{\mathrm{n}} \mathrm{H}_{2 \mathrm{n}+2}$ [22]. By modeling in the ANSYS system the deformations redistributed in the rocks surrounding the mine, where the explosion occurrs, it has been found that the waves generated by the explosive energy of the seismic type are significantly ahead of the explosion front moving in the gaseous medium. These waves cause the transition of coal particles from a powder state to a state suspended in air, as well as the formation of an explosionhazardous coal aerosol [23]. The given data make it possible to approach the disclosure of the explosion mechanism and its negative impact.

\subsection{Formulation of the research purpose and setting the problem}

The research purpose is to provide a theoretical assessment of the process of damaging factors formation during the coal aerosol explosion in mine workings, which makes possible to substantiate the promising methods of protecting miners from their impact.

To achieve the set purpose, the following tasks are consistently solved:

- the phenomena occurring during the explosion are summarized and a diagram of its development along the mine working is created, in which there is no methane or aerosol in explosion-hazardous concentrations;

- the energy state of gases is studied in the area, which is formed by the cross-section of the mine working, and which 
has a length per unit of length, sequentially located in differrent zones of the explosion;

- a theoretical analysis is conducted of the influence of factors that form the shock and fire front of the coal aerosol explosion.

The object of research is the physical-chemical processes occurring in the mine working during the coal aerosol explosion. The subject of research is the conditions and factors that determine the parameters of damaging factors formation in individual areas of mine working, where an explosion of coal aerosol occurs.

\section{Methods}

The approach used includes a retrospective review of underground accidents in Ukrainian mines associated with methane and coal dust explosions; critical analysis of literature data on the occurrence and development of coal aerosol explosions in mine workings; generalization and substantiation of the generalized mechanism of coal aerosol explosion development on the basis of practical and literary data; theoretical research on the state of gaseous medium at characteristic points of the explosion development diagram of coal dust deposits along the mine working using apparatus of classical physics and chemistry.

In particular, statistical data on explosions in mines for the period of 1978-2019 have been collected. In addition, a review of modern literary sources has been performed, which makes it possible to improve the understanding of the explosion development mechanism of dust deposits in mine workings. The schematization of the process of the explosion front sequential movement makes it possible to substantiate the expediency of thermodynamic analysis at individual points of the area formed by the cross-section of the mine working and having a limited length. Based on modern concepts of the processes of chemical and thermal oxidation of coal and methane, the dynamics of the explosion energy has been revealed. Using the known results of experimental studies, it is possible to clarify and confirm the results obtained.

Generalization of modern concepts about the phenomena occurring during the explosion makes it possible to create a diagram for its development along the mine working in which there is no methane or aerosol in explosion-hazardous concentrations (Fig. 1).

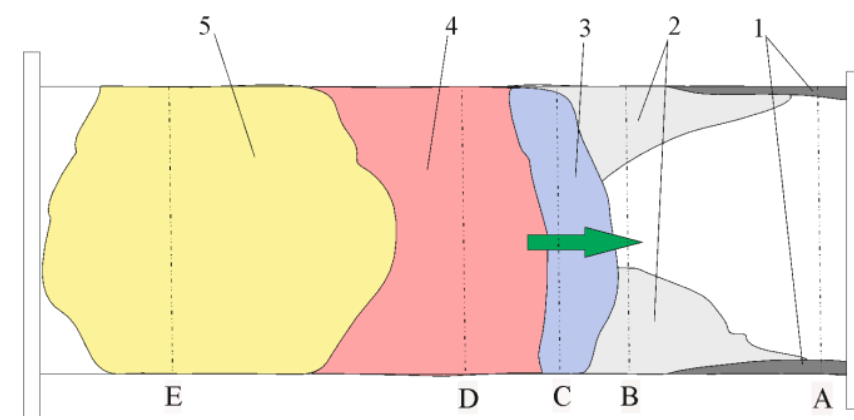

Figure 1. Diagram of the development of coal dust deposits explosion along the mine working (in the direction of the arrow): 1 - layers of coal powder; 2 - seismic-generated coal aerosol cloud; 3 - shock wave front of the explosion; 4 - fire front; 5 - gas cooling and discharge area; A...E-control sections
In the initial position (section $A$, Figure 1), coal dust is in the air, its concentration is much less than the level of the minimum flammability boundary, the bulk of the dust in the form of powder is concentrated on the bottom of mine working and other horizontal surfaces, and its smallest fractions are on the walls and the roof of mine working.

From the point of view of damaging factors formation, namely, high levels of gas pressure, temperature and gas flow rate, the formation of toxic gases, loss of oxygen with the appearance of an asphyxiant environment, with the development of coal dust explosions along a network of mine workings, it is advisable to study the energy state of the area in which there are no exogenous ignition sources. Such a conventionally distinguished area is formed by a crosssection of a mine working and has a length of a unit of length (for example, one centimeter), sequentially located in different explosion zones (Fig. 1) from the initial normal state $(A)$ to discharge and cooling $(E)$.

\section{Research results}

In the case of an explosion in the mine working, the fraction of its energy is distributed in the rock mass at a velocity exceeding the velocity of the explosion front movement in a gaseous medium. At the same time, in mine working areas located ahead of the explosion front, under the action of alternating rock vibrations, fraction of the powder transitions to aerosol state.

The usual composition of mine ventilation gases includes nitrogen and oxygen in a ratio of $7.8 / 2$, moisture in the form of vapor, the relative ratio of which is 80 to $100 \%$. The presence of methane in an amount of not more than $1 \%$ and carbon dioxide $-0.5 \%$ is allowed, but in reality these indicators may deviate in both directions. Other types of gases are present in insignificant amounts.

During the normal movement of the ventilation flow, the air is in a passive state under the external influence of the potential and kinetic energies of adjacent areas, which are inextricably linked with it. The mechanical energy $E_{m}$ of air in an elementary volume consists of potential $E_{p}$ and kinetic $E_{k}$ components of air mass:

$$
E_{m}=E_{p}+E_{k}=V g h \rho+V \rho \frac{v^{2}}{2}=V \rho\left(g h+\frac{v^{2}}{2}\right),
$$

where:

$$
\begin{aligned}
& V \text { - volume; } \\
& \rho \text { - air density; } \\
& g \text { - free fall acceleration constant; } \\
& h \text { - height of movement; } \\
& v \text { - ventilation flow velocity. }
\end{aligned}
$$

For horizontal mine workings, where there is no change in height, the potential energy can be neglected, and $E_{m}$ is determined only by the ventilation flow velocity.

When assessing the total energy $E_{s}$ in the studied volume, it should also be taken into account the state of the internal energy of gas molecules $E_{i n}$, mainly its thermal component, neglecting in this case the chemical and electrical components, given the practical absence of such processes.

As a first approximation, let us try to consider the ventilation stream as an ideal gas. Static physics gives the following equation of its state: 


$$
E_{v}=\frac{k R}{M} m T,
$$

where:

$m$-gas mass;

$M$ - gas molar mass;

$R$ - universal gas constant;

$k$ - the coefficient $\mathrm{k}=5 / 2$ for diatomic $\left(\mathrm{O}_{2}, \mathrm{~N}_{2}, \mathrm{H}_{2}, \mathrm{CO}\right)$ and 3 for polyatomic $\left(\mathrm{CH}_{4}, \mathrm{CO}_{2}, \mathrm{H}_{2} \mathrm{O}, \mathrm{C}_{2} \mathrm{H}_{2}\right.$ etc. $)$ gases;

$T$ - air temperature.

Under normal conditions, mine air consists mainly of diatomic oxygen and nitrogen, as well as triatomic water vapor, which have the same temperature. The ratio of their masses in the mixture is constant.

Thus, in general terms, the total energy of the air volume studied in section $A$ under normal ventilation mode is:

$$
E_{A}=E_{k}+E_{v}=V \rho \frac{v^{2}}{2}+V \rho \frac{k R}{M} T=m\left(\frac{v^{2}}{2}+\frac{k R}{M} T\right) .
$$

It is determined by factors such as the density of the medium, its velocity, gas composition and temperature.

During the explosion, seismic waves, which are ahead of the shock and fire fronts in the control section, act on the layers of coal powder and it transitions to a suspended state (position $B$, Figure 1). There is no significant change in velocity, gas composition and temperature. The increase in air density due to the low concentration of raised dust is insignificant. At the first approximation, the air energy in section $B$ can be calculated by Expression (3). It should be noted that in sections $A$ and $B$ the formation of negative factors does not occur.

When the shock front approaches and enters the specified volume (position $C$, Figure 1), the energy state indicators change qualitatively and quantitatively. The flow velocity $v_{l}$ increases to a level close to the Mach number. The volume $V_{l}$ decreases due to compression in the horizontal direction, and, accordingly, the density $\rho_{l}$ increases, but the gas mass in such a compressed volume remains unchanged:

$m=V \rho=V_{1} \rho_{1}$.

The gaseous medium composition, which is characterized by the indicator $\frac{k R}{M}$, remains unchanged. The temperature of the medium $T_{1}$ is functionally related to pressure. As a result of the compression of gases, it can reach hundreds of degrees Celsius (Fig. 2). When a shock wave propagates along a mine working at a velocity close to the Mach number, there is a sharp compression of gases and, accordingly, an abrupt increase in their temperature. On the graph, this corresponds to the beginning of the explosion, the temperature $T_{p}$ at the point $M_{1}$.

Thus, the change in the total energy of gases in the shock front is determined by an increase in the velocity of the shock front movement and the temperature of the compressed gas. In addition, an additional heat flux $E_{a d}$ in the form of radiation comes from the fire front following the shock front. The calculation of this indicator for the conditions of mine working is currently quite difficult due to the absence of a significant number of derived factors and requires a separate further study. Roughly it is taken as proportional to the Stefan-Boltzman law with an empirical coefficient $k_{1}$.
$E_{c}=m\left(\frac{v^{2}}{2}+\frac{k R}{M} T_{p}\right)+k_{1} \sigma T_{t}^{4}$

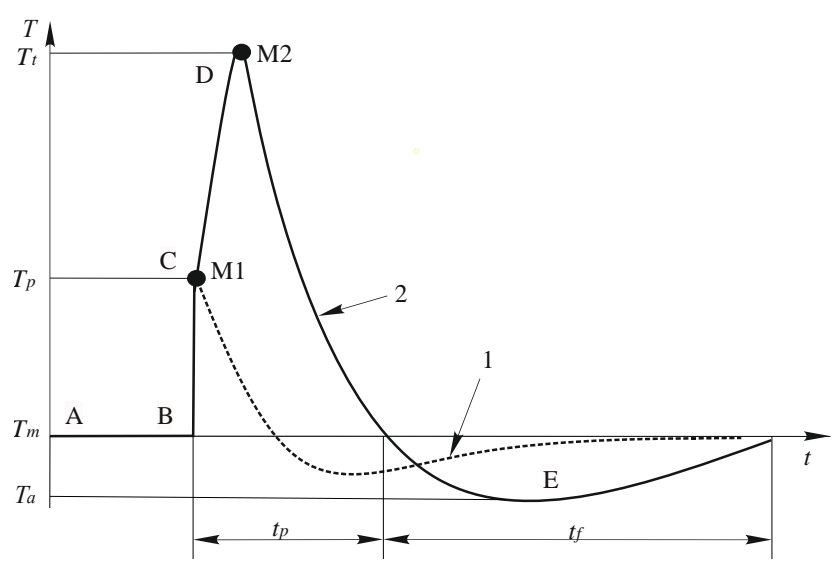

Figure 2. The dynamics of the gaseous medium temperature during the coal dust explosion: 1,2-temperature graphs of the consequences of methane (dotted line) and dust (solid line) explosions, respectively: $M_{1}, M_{2}-$ temperature peaks in the shock and fire fronts, respectively; $T_{m}, T_{p}, T_{t}, T_{a}$ - temperatures of the ventilation flow, compressed air, burning aerosol and rarefied air; $t_{p}, t_{f}-$ duration of compression and rarefaction periods, respectively; A...E-as in Figure 1

If there are no combustible components in the studied volume and no chemical reactions occur, for example, when a blast wave propagates after the methane mixture explosion, then the further course of the process can be characterized by the Rankine-Hugoniot adiabat, shown by dashed line 1 in Figure 2. When the combustible components are present in the volume, a change in the energy state occurs due to physical-chemical processes during the oxidation of combustible gases and coal. In Figure 2, this corresponds to the area $M_{1}-M_{2}$, the temperature increases to a maximum $T_{t}$, (position $D$, Figure 1). It is necessary to take into account the added chemical energy caused by the transition of the coal substance from the solid phase to the gaseous phase. Solid carbon combustion is a heterogeneous reaction occurring on its surface.

With complete oxidation of carbon:

$\mathrm{C}+\mathrm{O}_{2}=\mathrm{CO}_{2}+394, \mathrm{~kJ}$,

as follows from the equation, burning one kilogram of carbon requires about $2.3 \mathrm{~kg}$ of oxygen.

With incomplete combustion of carbon:

$2 \mathrm{C}+\mathrm{O}_{2}=2 \mathrm{CO}+221, \mathrm{~kJ}$,

in this case up to $1.3 \mathrm{~kg}$ of oxygen is required. It should be noted that in such a reaction, when one $\mathrm{O}_{2}$ molecule is consumed, two CO molecules are formed.

In addition, there is combustible methane in the initial ventilation air stream and layers of coal powder, which also oxidizes at high temperature:

$\mathrm{CH}_{4}+2 \mathrm{O}_{2} \rightarrow \mathrm{CO}_{2}+2 \mathrm{H}_{2} \mathrm{O}+891, \mathrm{~kJ}$.

Methane is present in two forms, namely in the ventilation air, and also, as mentioned above, is adsorbed on the surface of coal particles that rise from the mine working perimeter by vortex air flows during the high-speed movement of the shock front. 
The gas mixture energy, which is formed in the studied volume (position $D$, Figure 2) during the burn-up of a combustible medium, can be estimated based on the specific heat of the fuel combustion - a physical value that shows how much heat is released during the complete combustion of fuel weighing $1 \mathrm{~kg}$.

$Q=m_{c} q_{c}+m_{\mathrm{CH}_{4}} q_{\mathrm{CH}_{4}}$,

where:

$m_{c}, m_{\mathrm{CH} 4}$ masses of coal and methane, respectively;

$q_{c}=29.3 ; q_{\mathrm{CH} 4}=50.1-$ specific heats of coal and methane combustion, $\mathrm{MJ} / \mathrm{kg}$.

The process of carbon combustion, as indicated above, is accompanied by significant oxygen consumption. At pressure $P_{n}=600 \mathrm{~mm} \mathrm{Hg}$ and a temperature of $22^{\circ} \mathrm{C}$, the oxygen density is $\rho_{o x}=1.42987 \mathrm{~kg} / \mathrm{m}^{3}$, its content in the initial stream is close to $W=20 \%$. In addition, the share of the volume is occupied by water vapor, near $P_{\text {water }}=50 \mathrm{~mm} \mathrm{Hg}$. Thus, the mass content of oxygen in one cubic meter of mine air is:

$m_{o x}=\frac{\left(P_{n}-P_{\text {water }}\right)}{\sigma_{o x} W}=\frac{(600-50)}{600 \cdot 1.42987 \cdot 0.2}=0.26$.

In one meter long area of mine working with a sectional plane of $16 \mathrm{~m}^{2}$, there is about $4.2 \mathrm{~kg}$ of oxygen, and this is enough for the complete oxidation of $1.8 \mathrm{~kg}$ of carbon. Calculations show that when 1 gram of coal is burned, up to 93 liters of $\mathrm{CO}_{2}$ can be released, therefore, from $1.8 \mathrm{~kg}-167$ 400 liters or $167.4 \mathrm{~m}^{3}$, with incomplete coal combustion about $330 \mathrm{~m}^{3}$ of CO. Such a volume of gases is an order of magnitude larger than the mine working size, which leads to an abrupt increase in pressure and temperature in it. The increase in the volume of gases concentrated in the burning front is determined not only by such products that have formed as a result of chemical processes, but also by the heating of nitrogen and water vapor present in it.

As usual, much more than $1.8 \mathrm{~kg}$ of carbon is accumulated along the mine working perimeter, therefore, deficient oxygen is mainly spent on its incomplete oxidation with the formation of $\mathrm{CO}$. It is known that as a result of the carbon and oxygen reaction, both carbon oxides $\mathrm{CO}$ and $\mathrm{CO}_{2}$ are formed simultaneously, the velocity constants of reactions (5) and (6) mainly depend on temperature. At $T=1200^{\circ} \mathrm{C}$, both oxides are formed in equal quantities. At $T=1600^{\circ} \mathrm{C}$, $\mathrm{CO}$ is formed twice as much as $\mathrm{CO}_{2}$. It is known from the reference literature that the theoretical temperature of coal and natural gas combustion reaches $2010-2020^{\circ} \mathrm{C}$, which explains the prevalence of $\mathrm{CO}$ as a result of reactions. This temperature level leads to a sharp increase in the velocity constants of reactions, if a constant at $0^{\circ} \mathrm{C}$ is taken as a unit, then at the specified temperatures it will be $2 \cdot 10^{12}-2 \cdot 10^{24}$. This explains the high velocity of movement of the fire front of the explosion and the shock front that depends on it in the direction where oxygen and fuel are concentrated. A certain role is also played by the inertia of the gaseous medium, under the influence of which the increased mass of gases rushes, "skirting" the fronts in the direction of the reactions, creating rarefaction from behind.

Currently, it is not possible to perform a clear quantitative assessment of the energy consequences of carbon explosive combustion in a real mine working due to the influence of a significant number of insufficiently known factors influencing this process. It is known that even in a single coal sam- ple, the composition of thermal destruction products differs significantly based on the composition of the atmosphere, mode and temperature of heating, the presence of moisture, and the dispersed composition of dust [24].

The indicated Dependences (5-8) make it possible to make a qualitative assessment and become the basis for the predictive determination of the parameters of the physicalchemical properties of the medium in the fire front of the explosion. It should be noted that in section $D$, the mass of gases increases significantly to $m_{i}$ due to the formation of oxides from solid carbon. The temperature rises several times to $T_{t}$, the ratio of two and polyatomic gases in the mixture also changes to $M_{i}$. This should be taken into account when assessing the change in the state of the medium in the fire front of the explosion.

When the oxygen resource is exhausted, exothermic reactions generally stop. However, at high temperatures, processes of the second type occur, namely:

$$
\begin{aligned}
& \mathrm{C}+2 \mathrm{H}_{2}=\mathrm{CH}_{4}+75.3, \mathrm{~kJ} / \mathrm{mol} ; \\
& \mathrm{CO}+\mathrm{H}_{2} \mathrm{O}=\mathrm{CO}_{2}+\mathrm{H}_{2}+41.8, \mathrm{~kJ} / \mathrm{mol} ; \\
& \mathrm{C}+2 \mathrm{H}_{2}=\mathrm{CH}_{4}+75.3, \mathrm{~kJ} / \mathrm{mol},
\end{aligned}
$$

and other processes, such as decomposition of methane into carbon (soot) and hydrogen.

Solid coal substance undergoes complex transformations similar to those occurring during coking, such as heating to a high degree without the presence of oxygen, which is accompanied by the formation of liquid and gas components. From coal of medium degree of metamorphism, resinous substances are released that can undergo cracking.

Endothermic processes occur simultaneously:

$\mathrm{CO}_{2}+\mathrm{C}=2 \mathrm{CO}-173, \mathrm{~kJ} / \mathrm{mol}$;

$2 \mathrm{H}_{2} \mathrm{O}+\mathrm{C}=\mathrm{CO}_{2}+\mathrm{H}_{2}-80.3, \mathrm{~kJ} / \mathrm{mol}$.

The gaseous products of the explosion are a complex mixture. For example, as it is known from earlier tests conducted by Polish researchers [25], [26] that during the thermal destruction of coal at $900^{\circ} \mathrm{C}$, it is formed, \%: $18.39-$ hydrogen; 73.4 - carbon oxide; 2.8 - carbon dioxide; 4.38 methane; 0.32 - ethane; 0.08 - propane; 0.33 - propylene and isobutane together; 0.3 - hydrogen sulphide. The above processes are confirmed by the presence of coke and resinous deposits on the supporting elements of mine workings after the explosion. A significant amount of soot is always observed in the clouds of gases emitted from the experimental adits during the explosion.

The energy of gases concentrated in section $D$ can be calculated from the following expression:

$$
E_{D}=E_{k}+E_{v}+E_{a d}=m_{1}\left(\frac{v_{1}^{2}}{2}+\frac{k R}{M_{1}} T_{t}\right)+m_{c} q_{c}+m_{C_{4}} q_{C_{4}}
$$

The increase in energy is accompanied by an increase in the mass of the gas and its expansion, which should be considered as a moving system of material points. The faster this movement, the more its inertia that keeps the movement.

The pressure is transferred to the surrounding medium, forming a shock front in the air of the mine working cavity and mechanical (similar to seismic) waves in the rock mass. Part of the energy in the form of radiation is spent on heating the solid inclusions in the air (dust) and the walls of the mine working. 
The cessation of exothermic reactions due to the exhaustion of the oxidizing agent and the reducing agent resources, as well as the dissipation of energy in the form of mechanical, radiation and heat losses into the surrounding medium, determines a decrease in the energy state of gases. In Figure 2, this corresponds to the descending area of line 2 to the end point of the compression period $t_{p}$.

During exothermic reactions, gases are cooled, their intensity increases due to heat transfer to the supporting elements and rock mass. In addition, the gas mixture contains a significant amount of water vapor, which is the result of reactions, evaporation of free, film, capillary and sorbed water from rock and metal surfaces, as well as water in the ventilation flow.

With a decrease in pressure and temperature, vapor condensation occurs with the absorption of the so-called latent heat of vaporization, which sharply accelerates the process of cooling and lowering the pressure (position $E$ ). The mass of the gaseous medium significantly decreases to $m_{a}$, its composition changes due to the transformation of vapor into liquid, as well as the dissolution of some gases into it. The typical molecular mass level of gases is $M_{a}$. At the same time the velocity of a gas flow movement is reduced almost to 0 .

The pressure, density and temperature in the section $E$ drop significantly below atmospheric. The minimum energy of gases concentrated in the section can be calculated from the following expression:

$$
E_{E}=m_{a} \frac{k R}{M_{a}} T_{a} .
$$

Subsequently, after ventilation is restored, the energy state of the medium is restored to the level described by Expression (3).

\section{Discussion}

The performed theoretical research allows to reveal the main points of the mechanism of negative factors formation during the explosion of dust, which in a powdery state accumulates on surfaces along the mine working perimeter. This paper studies the process of damaging factors formation during the coal aerosol explosion in mine workings, which can reveal the main directions for protection of miners caught in the explosion.

One of the most significant factors is the impact of gaseous medium accelerated movement. Its influence consists in an abrupt increase in air speed, and the flow energy increases proportionally $\frac{v_{1}^{2}}{2}$ (Expression 4 ). This leads to the movement of objects and equipment, as well as people in the flow of gases, thereby causing mechanical injury. This manifests itself in the area $B C D$ (Fig. 2). This factor can only be overcome by stopping it with hard barriers. It is characterized by significant inertia, so even the suppression of detonation by fire-extinguishing substances does not protect people from air, which continues to move at high speed. The area of damage from this type of factor is the largest. It is possible to protect people from it not only behind barriers, but also in shelter chambers, if people are warned about the approach of the explosion front.

The velocity of explosion front propagation along the mine working often exceeds the velocity of sound in the air, therefore, people caught by the explosion by surprise do not have time to react and take protective measures. Many of the victims are unable to switch to the self-rescuers and are poisoned by toxic explosion products or die of suffocation (Expressions 5-13).

The most severe consequences are caused by the action of high temperature, which is formed during the detonation combustion of coal and methane, as well as from the compression of gases. This results in severe burns to the surface of the skin and the respiratory tract. The temperature level exceeds $1500-2000^{\circ} \mathrm{C}$ in the $C D$ area, later it slowly decreases to $T_{m}$, and even to $T_{a}$. The means of protecting miners from the effects of ultra-high temperatures are still unknown. Theoretically, it is possible to create shelters thermally isolated from emergency mine working. In order to use such a shelter, miners must have preliminary information about the arrival of the explosion front in order to have time to take a safe place. For production sites located at a distance from the explosion hypocenter, such a possibility exists when seismic waves, which are ahead of the blast waves, [27] are used as an indicator and provide an alarm signal a few seconds before the front arrives.

Another hazard factor is increased gas pressure, which leads to barotrauma of varying severity. It appears simultaneously with the previous one in the $B C D$ area and further until the pressure drops to levels that are safe for humans. Like ultra-high temperature, pressure is generated by the combustion of coal and methane (Expression 14). The resulting energy is determined by the amount of oxygen in the mine working. Thus, for the belt conveyor networks, it is advisable to provide an isolated ventilation mode and place it in mine workings with a minimum permissible crosssectional area. This ensures the minimum level of energy released during an explosion and minimizes all types of factors that negatively affect people and equipment.

\section{Conclusions}

The probability of methane-air mixtures and coal aerosols explosions in coal mines of Ukraine remains high, and their consequences are the most severe among underground accidents.

Most of modern scientific research is aimed at studying the explosiveness of artificially created aerosols of crushed coal and non-combustible solid or liquid impurities with air. There is not enough works devoted to the study of the explosion mechanism of coal deposited on the walls of mine workings. This impedes the development or improvement of methods and means of protecting people from the impact of negative factors of explosions.

Taking into account the influence of seismic waves, leading to the transition of coal deposits into a state suspended in the air, which create an explosion-hazardous dust and gaseous medium, the diagram of the explosion development of a settled coal dust in a mine working with normal ventilation conditions has been improved. This makes it possible to reveal the dynamics of energy processes occurring in the fire and shock fronts, which determine the mechanism of damaging factors formation.

A qualitative assessment has been performed and theoretical expressions have been obtained for calculating the kinetic, thermal and chemical components that determine the energy state of the gaseous medium in the characteristic 
places of the explosion front. In addition, the dynamics of the formation of negative explosion factors has been revealed. The obtained dependences reflect the linear dependence of the gas energy value at the characteristic points of the diagram and reveal the dynamics of the negative factors formation caused by dust explosion. The main factors determining the energy in the fire front are the masses of coal dust and methane contained in the section of the mine working, but the process of their oxidation is limited by the oxygen content in this volume.

Possible ways of protecting miners from the impact of negative factors of the coal aerosol explosion, as well as reducing the severe consequences of such accidents are proposed.

\section{Acknowledgements}

The authors express their gratitude to the management of the Donetsk National Technical University of the Ministry of Education and Science of Ukraine for their support during conducting the research and presenting the results.

\section{References}

[1] Kostenko, V., Zavialova, O., Krupka, A., Duz, L., \& Kraliuk, M. (2020). Tactics of elimination of consequences of the gas-dust mixture explosions in mining workins of coal mines. Scientific Bulletin of Donetsk National Technical University, 1(4)-2(5), 37-51. https://doi.org/10.31474/2415-7902-2020-1(4)-2(5)-37-51

[2] Kostenko, V., Gamiy, Y., Kostenko, T., Tsvirkun, S., \& Udovenko, M. (2021). Dynamics of motion of gases from a source of spontaneous combustion of coal in mine workings. Rudarsko-Geološko-Naftni Zbornik, 36(2), 109-117. https://doi.org/10.17794/rgn.2021.2.10

[3] Romanchenko, S.B., \& Kosterenko, V.M. (2018). Polnomasshtabnye issledovaniya vzryvov ugol'noy pyli i kriterii effektivnosti sredstv lokalizatsii. Vestnik Nauchnogo Tsentra po Bezopasnosti Rabot $v$ Ugol'noy Promyshlennosti, (4), 6-20.

[4] Bryukhanov, A.M. (2004). Rassledovanie i predotvrashchenie avariy na ugol'nykh shakhtakh. Chast' 1. Donetsk, Ukraina: Nord-Press, $548 \mathrm{~s}$.

[5] Lin, S., Liu, Z., Wang, Z., Qian, J., \& Gu, Z. (2020). Flame characteristics in a coal dust explosion induced by a methane explosion in a horizontal pipeline. Combustion Science and Technology. https://doi.org/10.1080/00102202.2020.1777548

[6] Li, H., Deng, J., Chen, X., Shu, C.-M., Kuo, C.-H., Zhai, X., \& Hu, X. (2020). Qualitative and quantitative characterisation for explosion severity and gaseous-solid residues during methane-coal particle hybrid explosions: An approach to estimating the safety degree for underground coal mines. Process Safety and Environmental Protection, (141), 150-166. https://doi.org/10.1016/j.psep.2020.05.033

[7] Pinaev, A.V., \& Pinaev, P.A. (2020). Combustion and detonation waves in gas mixtures of $\mathrm{CH}_{4} / \mathrm{Air}, \mathrm{CH}_{4} / \mathrm{O}_{2}$, and $\mathrm{O}_{2} /$ Coal dust. Combus tion, Explosionand Shock Waves, 56(6), 670-681. https://doi.org/10.1134/S0010508220060064

[8] Guo, C., Shao, H., Jiang, S., Wang, Y., Wang, K., \& Wu, Z. (2020). Effect of low-concentration coal dust on gas explosion propagation law. Powder Technology, (367), 243-252. https://doi.org/10.1016/j.powtec.2020.03.045

[9] Zhu, Z., Wang, H., \& Zhou, J. (2020). Monitoring and control model for coal mine gas and coal dust. Chemistry and Technology of Fuelsand Oils, 56(3), 504-515. https://doi.org/10.1007/s10553-020-01161-3
[10] Jiang, H., Bi, M., \& Gao, W. (2020). Suppression mechanism of al dust explosion by melamine polyphosphate and melamine cyanurate. Journal of Hazardous Materials, (386). https://doi.org/10.1016/j.jhazmat.2019.121648

[11] Niu, Y., Zhang, L., \& Shi, B. (2020). Experimental study on the explosion-propagation law of coal dust with different moisture contents induced by methane explosion. Powder Technology, (361), 507-511. https://doi.org/10.1016/j.powtec.2019.11.089

[12] Moradi, H., Sereshki, F., Ataei, M., \& Nazari, M. (2020). Evaluation of the effect of the moisture content of coal dust on the prediction of the coal dust explosion index. Rudarsko-Geološko-Naftni Zbornik, 35(1), 37-47. https://doi.org/10.17794/rgn.2020.1.4

[13] Pejic, L.M., Torrent, J.G., Añez, N.F., \& Escobar, J.M.M. (2017) Prevention and protection against propagation of explosionsin underground coal mines. Journal of Mining Institute, (225), 307-312. https://doi.org/10.18454/pmi.2017.3.307

[14] Kusainov, P.I., Mazepa, E.E., Kraynov, Yu.A., \& Lukashov, Yu.O. (2021). Considering the settling of dispersed water in the water barrier when calculating the explosion-proof distance at the methane explosion in a mine. Journal of Physics: Conference Series, 1749(1). https://doi.org/10.1088/1742-6596/1749/1/012042

[15] Kudryashov, V.V., Kubrin, S.S., Kosterenko, V.N., \& Tereshkin, A.I. (2020). Problems of dust control in coal mines. Mining Informational and Analytical Bulletin, 2020(1), 89-98. https://doi.org/10.25018/02361493-2020-1-0-89-98

[16] Perera, I.E., Harris, M.L., Sapko, M.J., Dyduc, Z., Cybulski, K., Hildebrandt, R., \& Goodman, G.V.R. (2020). Large-scale explosion propagation testing of treated and non-treated rock dust when overlain by a thin layer of coal dust. 2020 SME Annual Conference and Expo. https://doi.org/10.1007/s42461-020-00373-9

[17] Huang, Q., \& Honaker, R. (2016). Optimized reagent dosage effect on rock dust to enhance rock dust dispersion and explosion mitigation in underground coal mines. Powder Technology, (301), 1193-1200. https://doi.org/10.1016/j.powtec.2016.08.004

[18] Vogt, E. (2011). Hydrophobized limestone powder as an antiexplosive agent. Polish Journal of Environmental Studies, 20(3), 801-804.

[19] Qian, J., Liu, Z., Lin, S., Li, X., \& Ali, M. (2020). Study on microstructure characteristics of material evidence in coal dust explosion and its significance in accident investigation. Fuel, (265), 116992. https://doi.org/10.1016/j.fuel.2019.116992

[20] Lin, S., Liu, Z., Qian, J., \& Li, X. (2019). Comparison on the explosivity of coal dust and of its explosion solid residues to assess the severity of reexplosion. Fuel, (251), 438-446. https://doi.org/10.1016/j.fuel.2019.04.080

[21] Medich, L.M., Torrent, Kh.G., An'yez, N.F., \& Eskobar, Kh.M.M. (2017). Predotvrashchenie rasprostraneniya vzryvov metana i pyli v ugol'nykh shakhtakh. Zapiski Gornogo Instituta, (225), 307-312. https://doi.org/10.18454/RM1.2017.3.307

[22] Romanchenko, S.B., \& Trubitsyn, A.A. (2019). Mikroskopicheskiy metod analiza stepeni uchastiya pyli vo vzryvakh. Vestnik Nauchnogo Tsentra po Bezopasnosti Rabot v Ugol'noy Promyshlennosti, (3), 6-16.

[23] Kostenko, V., Liashok, Ya., Zavialova, O., Pozdieiev, S., \& Kostenko, T. (2020) The deformation dynamics of the experimental adit's material during a coal dust explosion. Eastern-European Journal of Enterprise Technologies, 4(7(106)), 54-62. https://doi.org/10.15587/17294061.2020.209409

[24] Romanchenko, S.B., \& Devlikanov, M.O. (2019). Vliyanie dispersnogo sostava pyli na pokazateli vzryvoopasnosti. Vestnik Nauchnogo Tsentra po Bezopasnosti Rabot v Ugol'noy Promyshlennosti, (2), 22-28.

[25] Cybulski, W. (1973). Wybuchy pylu weglowego $i$ ich zwalczanie. Katowice, Polska: Slask, $451 \mathrm{~s}$

[26] Lebecki, K. (2004). Zagrożenia pylowe w górnictwie. Katowice, Polska: Gílowny Instytut Górnictwa, 399 s.

[27] Kostenko, V.K., Zavialova, O.L., Lyashok, Ya.O., Kostenko, T.V., \& Tavrel', M.I. (2020). Prystrii dlia lokalizatsii vybukhiv vuhilnoho pylu. Patent \#143877. Ukraina.

\section{Теоретичні основи утворення вражаючих факторів під час вибуху вугільного аерозолю}

\section{О. Зав'ялова, В. Костенко, Н. Ляшок, М. Григор'ян, Т. Костенко, В. Покалюк}

Мета. Оцінка процесу утворення вражаючих факторів під час вибуху вугільного аерозолю в гірничій виробці на основі теоретичних досліджень вибуху вугільних пилових відкладень для обгрунтування перспективних шляхів захисту гірників від їх впливу.

Методика. Використано комплексний підхід, що включає критичний аналіз літературних даних щодо виникнення та розвитку вибухів вугільного аерозолю в гірничих виробках; теоретичні дослідження стану газового середовища в характерних точках схеми розвитку виробкою вибуху вугільних пилових відкладень на основі законів класичних фізики і хімії.

Результати. Розкрито основні аспекти механізму вибуху пилу, який знаходиться у порошкоподібному стані у вигляді скупчень на поверхнях по периметру гірничої виробки, і утворення негативних факторів, таких як дії прискореного руху газового середовища; високої температури що утворюється при детонаційному згорянні вугілля і метану; підвищеного газового тиску. Виявлення аспекти механізму вибуху пилу дали можливість встановити основні напрямки захисту гірників, захоплених вибухом. Удосконале- 
но схему розвитку вибуху осілого вугільного пилу у виробці з нормальними умовами провітрювання з урахуванням впливу сейсмічних хвиль.

Наукова новизна. Встановлено аналітичні залежності, що відображають величину енергії газів у характерних точках схеми, розкрито динаміку утворення негативних факторів вибуху.

Практична значимість. Запропоновано можливі шляхи захисту гірників від дії негативних факторів вибуху вугільного аерозолю та зменшення важких наслідків такого роду аварій.

Ключові слова: вибух, вугільний пил, вогневий фронт, ударна хвиля, сейсмічні хвилі, вражаючі фактори, захист гірників

\section{Теоретические основы образования поражающих факторов во время взрыва угольного аэрозоля}

\section{Е. Завьялова, В. Костенко, Н. Ляшок, Н. Григорьян, Т. Костенко, В. Покалюк}

Цель. Оценка процесса образования поражающих факторов при взрыве угольного аэрозоля в горной выработке на основе теоретических исследований взрыва угольных пылевых отложений для обоснования перспективных путей защиты горняков от их влияния.

Методика. Использован комплексный подход, включающий критический анализ литературных данных о возникновении и развитии взрывов угольного аэрозоля в горных выработках; теоретические исследования состояния газовой среды в характерных точках схемы развития выработкой взрыва угольных пылевых отложений на основе законов классической физики и химии.

Результаты. Раскрыты основные аспекты механизма взрыва пыли, находящейся в порошкообразном состоянии в виде скоплений на поверхностях по периметру горной выработки, и образования негативных факторов, таких как действия ускоренного движения газовой среды; высокой температуры образующегося при детонационном сгорании угля и метана; повышенного газового давления. Выявленные аспекты механизма взрыва пыли позволили установить основные направления защиты горняков, застигнутых взрывом. Усовершенствована схема развития взрыва отложившейся угольной пыли в выработке с нормальными условиями проветривания с учетом влияния сейсмических волн.

Научная новизна. Установлены аналитические зависимости, отражающие величину энергии газов в характерных точках схемы, раскрыта динамика образования негативных факторов взрыва.

Практическая значимость. Предложены возможные пути защиты горняков от действия негативных факторов взрыва угольного аэрозоля и уменьшения тяжелых последствий такого рода аварий.

Ключевые слова: взрыв, угольная пыль, огневой фронт, ударная волна, сейсмические волны, поражаюшие факторы, защита горняков 